\title{
Cristianizacion de la existencia y modernidad occidental. Sobre la genealogia del sujeto moderno en Max Weber
}

\author{
YOLANDA RUANO \\ Universidad Complutense de Madrid
}

Pretendemos mostrar la conexión significativa entre ciertas ideas religiosas y la consolidación de una subjetividad que objetiva toda la realidad como el ámbito legítimo dc complcto dominio práctico-instrumental. Dar cuenta de la, a un tiempo, afín y paradójica relación entre una concepción dualista y devaluadora del mundo, como la judeocristiana, y la elaboración de una imagen modema del mismo en la que el sujeto se constituye propiamente como tal a través de la sujeción racional teleológica de todos los procesos naturales, sociales y subjetivos. Interesa sobre todo resaltar el carácter paradóijico de esta relación: el hecho de que el desarrollo de la modernidad siga una lógica independiente opuesta al que fuera su sentido originario. Un cierto mecanismo de autodestrucción de la racionalidad valorativa parece, pues, inscrito en el proceso de modernización, mecanismo responsable, al fin, de que la expansión de la racionalidad de medios y fines se eternice como signo de modernidad.

\begin{abstract}
"Un paisano tiene por lo menos nueve caracteres: caráctcr profesional, nacional, estatal, de clase, geográfico, sexual, consciente, inconsciente y quizá todavía otro carácter privado; él los une todos en sí, pero ellos le descomponen, y él no es sino una pequeña artesa lavada por todos estos arroyuelos que convergen en ella, y de la que otra vez se alejan para llenar con otro arroyuelo otra artesa más» (Robert Musil, El hombre sin atributos).
\end{abstract}

\section{MONJE Y BURGUÉS: UN EXTRAÑO/EXTRAÑADO PARENTESCO}

Desentrañar el alcance significativo de ciertas creencias religiosas para la conformación de un método burgués de vida ${ }^{1}$ adecuado al desarrollo de la sociedad y cultura modernas es uno de los intereses medulares de Max Weber, una

'Cfr. «Resultat: Konfuzianismus und Puritanismus», en Gesamtausgabe, herausgegeben von Horst Baier, M. Rainer Lepsius, Wolfgang J. Mommsen, Wolfgang Schluchter, Johannes Winckelmann. Im Auftrag der Kommission für Sozial und Wirtschaftsgeschichte der Bayerischen Akademie der Wissenschaften. Abteilung I: Band 19; J.C.B., Mohr (Paul Siebeck), Tübingen, 1989, 
pieza clave que permite arrojar luz sobre «el» interrogante que recorre y ordena toda su extensa obra: el relativo a la especificidad del racionalismo occidental. La cuestión weberiana por excelencia es, en efecto, comprender el significado de la Modernidad desde el punto de vista de su racionalismo específico. En este sentido, interpreta muestro autor la Modernidad como siendo el resultado de un proceso de intelectualización-desencantamiento, patrimonio de la historia de Occidente, cuyo precipitado últímo es la expansión y consolidación legítima de la racionalidad formal (analítica y mesológica) y la consiguiente reclusión. también legítima, de la racionalidad sustantiva tradicional al terreno de lo subjetivo, de lo valorable, de lo plural y variable. Citando al Nietzsche de los Diarios de Robert Musil, diríamos que el modo singular de desarrollarse la razón moderna testifica que «la vida ya no habita en el todo (...) El todo ya no vive en absoluto: está compuesto, calculado; es artificioso, un artefacton ${ }^{2}$. Somos, sin duda, conscientes (en cuanto herederos de la Modernidad, ya nos autodefinamos como culminadores o transgresores de la misma) de que «la» racionalidad carismática ha perdido definitivamente su sustantividad en favor de formas de racionalidad plurales que rigen con validez autónoma los distintos órdenes de acción. $Y$ es verdad que la tan recalcada crisis de fundamentos aquí dibujada abre, sin duda, espacios ineludibles de perplejidad ante el politeísmo cosmovisional; pero también los abre de libertad irrenunciables, de posibilidades de procesos autoilustradores, y de desarrollo - tan difícil y a costa de tanto- de una subjetividad resistente frente a la expansión omniabarcante del racionalismo formal ${ }^{3}$. Porque si hay algo, en efecto, que identifique al proceso de racionalización occidental en el orden cultural, vital-personal y social es justamente la implantación en la era moderna de ese racionalismo puramente formal autoperpetuante, que da cuenta de la consolidación del moderno orden económico capitalista como eterno (1) «destino» de Occidente. La realidad de este orden que dirige, a todas luces, nuestra existencia —quién sabe si para siempre - presupone, a la vez que consolida, en efecto, la institucionalización de la acción racional conforme a fines en todas las esferas de la vida. El capitalismo moderno resulta, de una parte, sólo comprensible, sin duda, desde el racionalismo formal de una ciencia consciente de su neu-

p. 464 (citado como Resultat); trad. al castellano en Ensayos sobre sociología de la religión, por J. Almaraz y J. Carabaña, vol. I, Taurus, Madrid, 1983, p. 427 (citado como ESR).

${ }^{2}$ Robert Musil, Diarios (1899-1947/42), vol. I, Valencia, Edicions Alfons El Magnànim, 1994, p. 32. Como en tantos momentos de esta obra, Musil cita libremente un texto de El caso Wagner.

${ }^{*}$ Por «subjetividad resistente» no quiero apuntat a la simple y pura afirmación del Yo, al valor de independencia característico del tan traido y llevado «individualismo» contemporáneo, y que legitimaria una -impensable- «desocialización», tal y como to entiende Alain Renaut. Consiste, por contra, en rescatar el valor de la autonomía subjetiva: de la subjetividad como fundamento auto-legislador. Autonomía aquí supone la sumisión a un principio, ley a noma libremente aceptada, y la resistencia frente a toda normatividad heterónoma. Cfr. Alain Renaut, La era del individuo, Barcelona, Destino, 1993. Asimismo, Lindividu. Reflexions sur La philosophie du sujet, París, Hatjer, 1995. 
tralización ante las cuestiones de sentido (cuestiones recluidas ya en el terreno de lo subjetivo, donde se acomodan la ética, la estética, la erótica, y la religión); desde el racionalismo formal que caracteriza cl derecho positivo y la administración burocrática, y desde un estilo de vida ascético incondicionalmente orientado al cumplimiento de los fines que las instituciones imponen. Pero, de otra parte, el capitalismo se eterniza como sistema en la medida en que eleva la racionalidad formal a la categoría de racionalidad valorativa, eliminando la necesidad y la posibilidad de cualquier orientación de la acción que no persiga el único fin/valor ahora ya definitivamente supremo: la eficacia económica.

Pues bien, dada la perspectiva heurística idealista adoptada por Weber en su reconstrucción genealógica de la modernidad así entendida, es una pieza clave en esa reconstrucción, según señalamos, la interpretación del modo en que ciertas «imágenes» religiosas del mundo conforman -a la larga y a su pesar, como veremos - un estilo de vida metódico-racional en el que quedan valorativamente ancladas las orientaciones de acción racionales con arreglo a fines. Lo que aquí está en juego es el nexo significativo existente entre el desarrollo de una imagen del mundo desencantada, que es, paradójicamente, la imagen cristiana del mundo, y la consolidación de una metódica conducción de la vida hacia el dominio teleológico de la realidad ${ }^{4}$. Se trata, en pocas palabras, de rastrear las condiciones subjetivas de la modernización.

Dirige su mirada Weber, como es sabido, hacia aquellas formas de protestantismo que encierran una ética ascética vuelta al mundo: hacia el denominado "protestantismo ascético». Sus representantes históricos son el calvinismo, en la forma que adoptó principalmente a lo largo del siglo xvir, el pietismo, el metodismo y las sectas nacidas del movimiento baptista, englobadas éstas en el complejo movimiento que se conoce como "puritanismo" inglés y holandés. Si se toman en consideración estas confesiones religiosas en conjunto es porque a pesar de las diferencias dogmáticas entre ellas, aun las más importantes, como las referentes a la justificación y la predestinación, todas contribuyen en el mismo sentido a la racionalización práctica, esto es, estimulan por igual la orientación ascética del modo de vida "vuelto al mundo» que caracteriza al sujeto moderno ${ }^{5}$. Una tal orientación sistemática de la conducta está valorativamente dirigida al dominio racional de la realidad; se desarrolla

${ }^{4}$ La relación entre la racionalización teórica y la práctica guía todo $\mathrm{el} \mathrm{análisis} \mathrm{weberiano}$ de la racionalización religiosa. Cfr. sobre todo Wirschaft und Gesellschaft. Gnindiss der vertehenden Soziologie. Fünfte, revidierte Auflage, besorgt von Johannes Winckelmann, J. C. B. Mohr (Paul Siebeck), Tübingen, 1980, II, V, §10, pp. 321-348 (citado como WG); en castellano Economia y sociedad, México, FCE, 1984, pp. 420-452 (ES), donde se propone como título de ese décimo parágrafo: «Los caminos de salvación y su influjo en los modos de vida».

No considera ni el movimicnto debido a Zwinglio, por su breve predominio, ni el calvinismo moderado de Arminio (surgido dentro del baptismo), porque los efectos que éste produce sobre la acción son contrarios a los buscados. Al rechazar el dogma de la predestinación - esencial, según veremos, para lo que buscamos-y afirmar, en consecuencia, la universalidad de la redención aborta, en efecto, el impulso a la racionalización del modo de vida hacia el dominio práctico-racional 
en el ejercicio profesional y tiene como premisa la racionalización del tiempo como tiempo de trabajo/ocio y el autodominio ascético de las pasiones. De sujetos así, entregados por deber a las exigencias del día a día, esto es, doblegados incondicionalmente a los imperativos que rigen la actividad en cada esfera vital, se nutren el capitalismo y el Estado modernos, necesitados, sin duda, de un nivel científico-tecnológico determinado, de una jurisprudencia formal y de una administración máximamente racional...; pero también de individuos impulsados por un deber incondicionado al cumplimiento de los fines que el sistema capitalista impone: el dominio técnico-formal de toda la realidad.

La aportación del luteranismo a esta cuestión no pudo escapársele a Weber, pero la consideró, con todo, parcial, puesto que, si bien vino por vez primera a valorar éticamente el trabajo secular, mantuvo, no obstante, una concepción tradicionalista del mismo, nada afín a esa glosada racionalización del estilo de vida que caracteriza al sujeto moderno. Aunque con la desaparición de la distancia católica entre los praecepta y consilia evangélicos, quedasen homologadas desde un punto de vista ético-religioso todas las ocupaciones humanas, éstas carecían, sin embargo - desde la óptica de quien reforzó, como lo hizo Lutero, la justitificación por la fe-, de «eficacia» redentora. Es decir, la ocupación profesional era, para Lutero, un «estado», que debía ser asumido de forma inalterable por ser impuesto por la divinidad. Sin duda. Pero en cuanto pura «exterioridad» se contraponía a la lógica emancipadora, lógica ésta inscrita exclusivamente en la interioridad del creyente, en una subjetividad confiada en ser «la» morada de lo divino ${ }^{6}$.

No deja de advertir Weber, sin embargo, que al investigar la estrecha relación de afinidad entre la antigua ética protestante y el ethos moderno, en ningún caso pretende afirmar, como cabría suponer, que los representantes mismos de las confesiones aludidas tuvieran como finalidad de su trabajo la creación de ese nuevo ethos social y cultural que da cuenta del sujeto moderno, ni que tan siquiera lo impulsaran de un modo directo ${ }^{7}$. La intención de su

del mundo (cfr. Gesammelte Aufsätze zur Religionssoziologie (GAR), J. C. B. Mohr (Paul Siebeck),

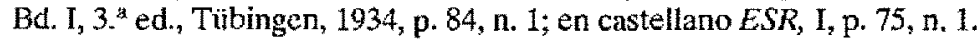

"Sobre esta parcial aportación, cfr. mi trabajo para Revista de Filosofia, 3." época, vol. XI (1998), num. 19, pp. 131-152, acerca de la raíz religiosa del deber profesional.

${ }^{\prime} \mathrm{Cfr} . G A R, \mathrm{I}$, p. $81 ;$ ESR, I, p. 72 . Del mismo modo que no puede atribuirse una relación directa entre la intención de la actividad reformadora del protestantismo ascético y sus efectos para el desarrollo del racionalismo económico moderno, tampoco puede fundarse en favor de la ausencia de afinidad entre el ethos luterano y el capitalista el hecho mismo de la aversión del propio Lutero a la actividad de los grandes comerciantes como los Fugger (cfr, $G A R$, p. 72, n. 3; ESR, I, p. 65). De lo contrario, vendria a soslayarse lo siguiente: por un lado, la centralidad de la idea de la paradoja de las consecuencias en el análisis weberiano de la génesis de la modernidad, $y$, por otro, la caracterización que Weber hace de la esencia del capitalismo moderno y de su ethos espeeffico. Como hemos apuntado en otro lugar (cfr. Racionalizad y conciencia trágica. La modernidad segun Max Weber, Madrid, Tratta, 1996, pp. 173 y ss.), el espiritu del capitalismo no se identifica con la avidez de lucro, sino justamente con la racionalización de la actividad orientada a ese fin, que adquiere así el nombre de «adquisición de beneficios». No es, por lo 
actividad reformadora respondía exclusivamente a fines religiosos - la salvación-, y no a la directa creación de una ética social reforzadora de un tipo de acción teleológica imperante en todos los órdenes de realidad ${ }^{8}$. $\mathrm{Y}$, sin embargo, esa forma de orientar la conducta y los efectos socio-culturales ligados a ella (el capitalismo moderno) pueden entenderse como resultados ni buscados ni queridos del desarrollo de la ética ascética protestante. No hay que olvidar que la paradoja entre intención y destino recorre a menudo la historia, y que, en este sentido, los efectos de la Reforma en el orden institucional y cultural son, en parte, consecuencias espontáneas, laterales e incluso opuestas al fin originariamente pretendido: orientar la conducta conforme a un valor religioso supremo ${ }^{9}$. Es más: justamente este resultado paradójico, que permite emparentar una cultura plenamente secularizada, destinada específicamente a la inmanencia y fundada en valores utilitaristas, con una religión de salvación, o, mejor, con la ética que le es propia, devaluadora del mundo y orientadora de la conducta hacia bienes de salvación, es, en definitiva, el punto decisivo que a Weber le interesa resaltar. En pocas palabras: el parentesco entre la cristianización de la existencia y el desencantamiento o la «desdivinización» de la misma como pilares de la modernidad.

Para comprender, en cualquier caso, la significación histórica que una determinada ética ascética religiosa pudo tener en el desarrollo de cierto estilo de vida, $y$, con él, de ciertos marcos institucionales y de cierta forma de cultura, cuyo rasgo compartido por todos ellos es ser la expresión consciente de una racionalidad que opera con medios y con fines sin apelar a instancias trascendentes a los mismos, Weber precisa distinguir entre la doctrina teológica y ética oficial, las implicaciones psicológicas y pragmáticas de esa doctrina teórico-ética, y el tipo de conducta que efectivamente provoca. Viene a exponer, pues, el proceso por el que cierto sistema de creencias se erigió en el fundamento práctico-moral de un particular tipo de acción. Así no le importa tanto la concepciôn dogmática, cuanto «indagar cuáles fueron los impulsos psicológicos

demás -y ahondando en el problema de las consecuencias no buscadas- sólo Lutero quien se opone a las grandes compañias comerciales y a la actividad especulativa, sino también Calvino, no menos que los hugonotes y los puritanos (contra los lombardos, trapecitas y monopolistas), o el catolicismo mismo, guiado por el principio Deo placere vix potest (cfr. GAR, I, p. 57; ESR, I, p. 53). Es más: incluso esa actitud es comparable a la extendida en la era misma del capitalismo desarrollado contra los grandes trusts económicos, y nadie se atrevería a afirmar por ello que seamos portadores de una mentalidad tradicionalista, en sentido weberiano.

${ }^{*}$ Cfr. GAR, I, p. 82; ESR, I, p. 73.

"Cfr. Resultat, p. 464; ESR, I, p. 427, donde Weber aclara qué entiende por el recurrente concepto de udestino». Este término es utilizado por Weber para sefialar siempre la relación invertida que a menudo se establece entre las intenciones de una acción y sus resultados. En el protestantismo ascético se deja sentir la kparadoja entre el efecto y la voluntad, hombre y destino (destino como consecuencia de su acción frente a su intención): esto es lo que nos puede enseñar esta inversión de lo "natural", que sólo parece chocante en un primer golpe de vista superficial\%. Como se sabe, el tema de las paradojas de las consecuencias germinará en la teoría funcionalista de Merton. 
creados por la fe religiosa y la práctica de la religiosidad que marcaron la orientación del modo de vida y mantuvieron dentro de ella al individuo» ${ }^{10}$.

Pues bien, si lo que interesa exclusivamente son los efectos de un sistema de ideas para la orientación de la acción, y éstos, por su parte, son consecuencias no directamente deducidas ni de los fundamentos teóricos (credos) ni de las doctrinas éticas dogmáticas, cabría pensar que la investigación subsiguiente prescindiera de ellos y se ocupara simplemente de la práctica moral ascética resultante. Sin embargo, y aun sin eludir el problema de la paradoja de las consecuencias, no puede ignorarse que los impulsos práxicos enraizan, en buena parte, en la forma del credo rcligioso, esto es, en la concepción de lo divino, del mundo y de las relaciones posibles entre ellos: "Los elementos racionales de una religión, su "doctrina" (...) tienen también sus propias leyes, y la pragmática religiosa racional de la salvación que se deriva del tipo de "imagen del mundo" y de Dios ha tenido, en determinadas circunstancias, consecuencias importantes para la configuración del estilo práctico de vida ${ }^{1 \mathrm{t}}$.

Así pues, comienza Weber con la exposición de los rasgos centrales de la doctrina calvinista, pero prologada todavía por una doble restricción. Aclara primero que no trata los principios de la teología del propio Calvino, sino del calvinismo en la forma en que se presenta a finales del siglo XVI y a lo largo del xvII en las zonas donde existía una mayor presencia de la economía capitalista (premoderna): Países Bajos, Inglaterra y Francia ${ }^{12}$. Y señala también, como no podía ser de otro modo, que para la caracterización de esa doctrina se sirve del instrumento metodológico adecuado a la investigación histórico-cultural, el método típico-ideal. Siendo éste un constructo lógico-teórico que se obtiene mediante la «interesada» selección y acentuación unilateral de ciertos aspectos de la realidad heurísticamente relevantes, de la dogmática calvinista Weber aísla la noción de «predestinación», tomándola como el elemento significativo cn su interpretación genética del desarrollo del moderno «estilo de vida» ${ }^{13}$. En este sentido puede suceder que to que desde el punto de vista histórico-cultural aparece como significativo, puede no serlo, y hasta resultar superficial, desde una consideración estrictamente teológica; pero Weber subraya en repetidas ocasiones que justamente los aspectos más externos de la religión y no los puramente dogmáticos son los que generalmente interesa subrayar, habida cuenta del influjo que ejercen en el orden de la acción. El dogma de la predestinación es, como decimos, el originario "caldo de cultivo» del ethos ascético profesional; sin él, la nueva ética, que tanto influyó en el terreno

${ }^{10}$ GAR, I, p. 86; ESR, I, pp. 76-77.

" wDie Wirtschaftsethik der Weltreligionen (Vergleichende religionssoziologische Versuche). Einleitung", еп Gesamtausgabe, J. C. B. Mohr (Paul Siebeck), Tübingen, 1989, Bd. 19, p. 109 (citado como Einleitung); en castellano «La ćtica cconómica de las religiones universales», en Ensayos sobre sociologia de la religión, ed. cit., p. 209 . Cf́r. $W G, \mathrm{II}, \mathrm{V}, \S 10$, p. $325 ; E S$, p. 425.

${ }^{2}$ Cfr. GAR, I, pp. 87 y 89, n. 1; ESR, I, pp. 78 y 79, n. 7. Prescinde de Alemania por no haber sufrido el influjo calvinista en zonas demasiado extensas.

1. $G A R$, I, p. 87, n. 2; ESR, I, p. 77, n. 4. Cfr. $G A R, \mathrm{I}$, p. 18, n. 1 . 
de la acción, no hubiera sido posible. Y aun cuando en la evolución posterior de las confesiones protestantes fue perdiendo vigencia, el arraigo de ese ethos ascético era ya tan fuerte que persistió en ellas en ausencia de su primitivo fundamento dogmático ${ }^{14}$. El análisis de ese dogma permite, en definitiva, captar la relación entre una cierta concepción religiosa del mundo y el surgimiento de unas estructuras de conciencia práctico-morales postradicionales ${ }^{15}$. Sólo por él - dice Weber - «comprendemos cómo iba vinculada la moralidad con el pensamiento sobre el más allá que dominaba a los hombres más cspirituales de la época, y sin cuyo poder supremo no hubiera podido realizarse ninguna renovación ética que de modo serio aspirase a influir en la praxis vital» ${ }^{16}$.

\section{a) De «decretum horribile»: Fundamentos dogmáticos del racionalismo ascético}

¿De dónde surge la idea de la predestinación? Weber señala que esta idea calvinista, cuyo contenido auténtico queda recogido en la Confesión de Westminster (1647), resulta de la racionalización del monoteísmo judeocristiano, esto es, del concepto de un Dios ético dotado «de los atributos de absoluta inmutabilidad, omnipotencia y omnisciencia; cn una palabra, con el carácter de un ser que se cierne en absoluto sobre el mundo» ${ }^{17}$. Un Dios así concebido, suprema majestad trascendente al mundo, de poder ilimitado sobre sus criaturas, es proclive a una visión teocéntrica y providencialista: «a interpretar por todas partes su "Providencia", su intervención personal en el curso del mundo» ${ }^{18}$. Pero Providencia y predestinación no pueden sino permanecer lógicamente unidos. Tal conexión racional fue vista y desarrollada por Calvino en todas sus consecuencias, y en este sentido considera Weber que el decretum homibile no es algo experimentado, sino reflexionado; no es producto de una vivencia, ni de una revelación, sino de una deducción racional de la concepción del

${ }^{14}$ Cfr. GAR, I, pp. 85-86; ESR, I, p. 76. Buena parte del segundo estudio sobre la ética protestante se fija justamente en ir señalando la evolución protestante en relación con el así considerado eje dogmático del calvinismo: la idea de la predestinación y del particularismo de la gracia, centrales en el siglo xvn entre calvinistas, presbiterianos y la segunda generación metodista (Whitefield) (cfr. $G A R, \mathrm{I}$, p. 125; $E S R, \mathrm{I}, 106$ ). El pietismo, por su lado, a pesar de su paulatina evolución hacia la aceptación de medios sentimentales de comprobación de la gracia que lo acercaban al luteranismo (evidente con Zinzendorff), mantiene la misma ética ascética que impulsa el desarrollo de esa metodización de la vida según ideales ascéticos.

${ }^{15}$ Cfr. GAR, I, p. 125; ESR, I, p. 106.

${ }^{16} G A R, \mathrm{I}, \mathrm{p}, 86 ; E S R, \mathrm{I}, \mathrm{p} .76$.

"Wirtschaft und Gesellschaft. Grundiss der vertehenden Soziologie. Fünfte, revidierte Auflage, besorgt von Johannes Winckelmann, J. C B. Mohr (Paul Siebeck), Tübingen, 1980, II, V, \$8, p. 315 (citado como WG); en castellano, Economia y sociedad, México, FCE, 1984 (ES), p. 412.

${ }^{18} W G, \mathrm{II}, \mathrm{V}, \S 8$, p. $317 ; E S$, p. 415. 
Dios de nuestra tradición: de la idea de un Dios trascendente y providente que dispone de los destinos individuales ${ }^{19}$.

La predestinación calvinista asume, según esto, en toda su radicalidad y consecuencia, la genuina noción del Deus absconditus con la que la tradición judeocristiana elabora una respuesta racional al problema de la teodicea, esto es, al problema de conjugar la existencia de un Dios ético con la evidencia del sufrimiento inmerecido. Es la respuesta expuesta en el Libro de Job ${ }^{20}$. Para esta tradición, la conciliación racional de una cultura supuestamente cargada de culpa moral, responsable del mal en cualquiera de sus manifestaciones, y la de también un supuesto Dios omnisciente, creador y preservador de esa rcalidad, impulsa a la razón a acentuar el abismo en un sentido ćtico, esto es, a radicalizar la distancia entre ellos hasta colocar a ese Dios absolutamente perfecto más allá de las pretensiones de las criaturas cargadas de imperfección. La devaluación de la razón para las cuestiones de sentido y de la voluntad para intervenir en el proceso de redención es el obvio resultado de esta acentuación. La afirmación agustiniana de la cficacia redentora de la gracia inmerecida o el Dios voluntarista de Ockham se encuentran en esta línea de pensamiento, línea que, como sabemos, desemboca en Lutero, quien, sin embargo, también huyó, con el catolicismo, de la predestinación. El reformador, en efecto, aunque formalmente nunca renunció a la idea de que la fuente absolutamente única y gratuita del estado de gracia fuera el «designio inescrutable» de la divinidad, atenuó, sin embargo, esta idea al apelar al Dios Padre del Nuevo Testamento más cercano y comprensible para el hombre e incluso éticamente cualificado con atributos humanos ${ }^{21}$. Calvino y el calvinismo priman, por el contrario, la concepción de un ser «trascendente e inaccesible a toda humana comprensión, que desde la eternidad ha asignado a cada cual su destino según designios totalmente inescrutables, y que ha dispuesto el más mínimo detalle en el $\operatorname{cosmos}^{22}$.

19 El catolicismo, por el contrario, ha realizado «multiples e inconsistcntes ensayos para combinar la responsabilidad del individuo con la predestinación y la providencia de Dios, para salvar la "libertad" empírica de la voluntad» (GAR, I, p. 93, n. 1; ESR, I, p. 82, n. 16).

${ }^{3}$ Cfr. WG, II, V, \& 8, p. 315. En ESR, I, p. 147, Weber menciona otras dos soluciones al problema de la teodicea: el denominado adualismo ontológicon, reflejado en la doctrina del Karma, y el dualismo zoroástrico.

"Cfr. GAR, I, pp. 91-92; ESR, 1, pp. 80-81. Cfr. Ernst Troeltsch, El protestantismo y el mundo moderno, trad. E. Imaz, México, FCE, 1951, p. 40; Konrad Algermissen, Iglesia católica y confesiones cristianas, Madrid, Rialp, 1964, p. 856.

${ }^{22}$ GAR, I, p. 93; ESR, I, p. 82. Tanto Lutero como Calvino fueron conscientes de esa doble concepción de Dios asumida por la tradición judeocristiana: el Padre cualificado éticamente del Nuevo Testamento y el Dios voluntarista, pura acción libre, del Antiguo. Ambos mantuvieron las dos concepciones en distintos momentos: Lutero en De la libertad del cristiano afirma la inescrutabilidad de los designios divinos sobre el destino individual, y Calvino, por su parte, en la Institutio Christiana astume el Dios Padre bondadoso (cfr. $G A R$, I, pp. 91-92, n. 1). En Lutero, no obstante, y aún más en el luteranismo, el concepto de predestinación se matiza (Melanchton expresamente lo rechaza, y para los padrcs de la Iglcsia luterana cra dogma incontrovertible 
En suma, la idea de predestinación es elaborada desde la noción de un Dios trascendente, del que cabe afirmar la acción como su esencia: «La esencia de lo divino es un "hacer" activo en el gobierno personal y providente del mundo» ${ }^{23}$. Y su inescrutable y libre voluntad como la exclusiva fuente del mundo. Desde sí mismo crea el mundo para aumento de su gloria, en un acto de «autoparto» divino y de autocontemplación complaciente. El posible sentido de este acto está inscrito en los propósitos divinos, en principio, jamás revelados. Toda la creación responde, por tanto, a un único fin: ser un medio para honra de su Majestad. Junto a esta noción, el hombre, como todo lo creado, no puede ser sino mero instrumento de lo divino: «Dios no es por los hombres, sino los hombres son por y para Dios, y todo cuanto sucede (...) no tiene sentido sino en calidad de medio para el fin de que la Majestad de Dios se honre a sí misma» ${ }^{24}$. Pero además el hombre es naturaleza caída, vacío ontológico, y todo su actuar lleva en sí el estigma del pecado, y aun en cl supuesto de que dcjase de estar «doblado sobre sí mismo» y quisiera el bien, de resultas produciria el mal.

La relación hombre-Dios está mediada por esta consideración de la naturaleza de ambos, que viene a reflejar el abismo inquebrantable entre cllos: «Toda criatura está separada de Dios por un abismo insondable, y ante él todos merecemos muerte eterna, salvo decisión suya en contrario, con el solo fin de hacer honra a su propia majestad» ${ }^{25}$. Desde este dualismo entre un Dios que impone un orden ćtico y unas criaturas enredadas en una nueva culpa es fácil concluir la incapacidad de la razón para comprender los designios divinos y la incapacidad de la voluntad y de la acción humana para colaborar en el proceso de salvación. Parece, en efecto, de un lado, que no nos compete, a esta luz, más que atenernos a la verdad eterna de que sólo Dios es libre, «no está sometido a ley alguna, y sus designios sólo pueden ser comprensibles y aun conocidos en tanto que le plugo comunicárnoslos» ${ }^{26}$. Todo lo demás, el sentido último de la creación y de nuestro destino individual, está velado a la inteligencia humana: «está rodeado de tenebrosos misterios, que es temerario e imposible tratar de aclarar» ${ }^{27}$. Pero, por otra parte, y como recoge el capítulo «Sobre el libre albedrío» de la citada Confesión: «Al caer el hombre en el pecado, su voluntad ha perdido completamente la capacidad de encaminarse al bien espiritual y a la bienaventuranza, de modo que el obrar natural,

que la gracia podia perderse y recuperarse por la confianza en la Palabra y por los sacramentos), mientras que Calvino profundiza en el abismo hasta rechazar toda vía sentimental de salvación y el resquicio místico del Juteranismo.

${ }^{2 *} W G, \mathrm{II}, \mathrm{V}, 8$ 8, p. 317; ES, p. 415.

${ }^{24}$ GAR, I, p. 92; ESR, I, p. 81. Cfr. WG, II, V, $\$ 8$, p. 317; ES, p. 415. "Totum mundum hoc fine condidit, at gloriae suae theatnm forts (Calvino, Obras, 8, 294. Apud: K. Algermissen, o.c, p. 855).

7. GAR, 1, p. 93; ESR, I, pp. 81-82.

${ }^{2 \hbar} G A R, 1$, pp. $92.93 ; E S R, 1$, p. 81 .

"GAR, 1, p. 93; ESR, I, p. 81 . 
apartado por completo del bien y muerto en el pecado, no es capaz de convertirse ni aun de prepararse para ello» ${ }^{28}$.

Así pues, la solución teórica del dualismo ético no puede ser otra, desde esta perspectiva, que la predestinación. Ella cierra definitivamente la pregunta por el sentido, pone diques al avance de la razón metafísica y desplaza a la voluntad humana de cualquier participación en el proceso de salvación. Pues lo único aprehensible por revelación bíblica es, en definitiva, que el sentido del mundo queda encerrado en la insondable voluntad divina, y, con él, el camino de salvación. Sabemos que ese Dios inaccesible a toda comprensión humana, «desde la eternidad ha asignado a cada cual su destino según designios totalmente inescrutables» ${ }^{29}$, ante los que no cabe aplicarles el criterio de la «justicia» humana, ni afectar de alguna forma sobre ellos sin detrimento de su majestad. Porque suponer que «el mérito o la culpa humana colaboran cn este destino significaría tanto como pensar que los decretos eternos y absolutamente libres podrían ser modificables por obra de los hombres: lo cual es absurdon ${ }^{30}$. La elección no constituye, pues, un premio o un castigo a los actos temporales, aun cuando sean revelados por las Escrituras como agradables a la divinidad: ella es el exclusivo resultado de la gracia inmerecida. Y así «la gracia divina, por ser inmutables los designios de Dios, es tan inadmisible para el que le ha sido concedida como inalcanzable para el que le ha sido negada» ${ }^{31}$. Pues bien, el capítulo tercero de la confesión de Westminster expresa así esta doctrina del doble decreto de la elección y la reprobación:

«Para revelar su majestad, Dios por su decreto (...) ha destinado (predestinated) a unos hombres a la vida etema y sentenciado (foreordained) a otros a la muerte eterna. Aquellos hombres que han sido elegidos a la vida han sido elegidos para gloria eterna por Dios, antes de la creación, por su designio eterno e inmutable, su decreto secreto y el arbitrio de su voluntad, y ello por el libre amor de su gracia (...). Plugo a Dios olvidarse de los restantes mortales, siguiendo el inescrutable designio de su voluntad, por el que distribuye o se reserva la gracia como le place, para honra de su ilimitado poder sobre sus criaturas» ${ }^{32}$.

2" Cap. 9 («Del libre albedrio»), n. 3 de la Westminster Confession (1647). Apud: GAR, I, p. 91; ESR, I, p. 79.

${ }^{29} G A R, \mathrm{I}$, p. $93 ; E S R, \mathrm{I}$, p. 82.

Ibidem.

"Ibidem.

${ }^{32}$ Cap. 3 («Del eterno decreto de Dios»), n. 3. Apud: GAR, I, p. 90; ESR, I, p. 79. «Nosotros afirmamos que Dios ha establecido como un decreto etemo e inmutable a quiénes concederá un día la participación de la vida bienaventurada y a quiénes los consagrará para la perdición» (Calvino, Obras, 2, pp. 683-786. Apud. K. Algermissen, o.c., p. 856). 
b) En el fondo del abismo: De la «sola fides» a la wides efficax»

La doctrina de la predestinación viene, como decimos, a representar para Weber un sistema de pensamiento capaz de ofrecer una respuesta racionalmente satisfactoria a la cuestión que acucia a la razón impulsando el proceso de racionalización teórica: el problema del fundamento de la incongruencia entre destino y mérito ${ }^{33}$. En este sentido, en consonancia con la caracterización weberiana del término «racionalización» en su doble dimensión teórico-práctica, el decreto predestinacionista completa la evolución del racionalismo religioso en la dirección del pleno desencantamiento teórico y práctico del mundo. Y es que el grado de racionalización de una imagen del mundo se mide, para Weber, según dos criterios. De un lado, por el mayor dominio teórico de la realidad, esto $\mathrm{cs}$, de sistematización interpretativa de la misma mediante la utilización de conceptos abstractos cada vez más precisos. De otro, por la mayor racionalización ética de la conducta, esto cs, por la orientación sistemática y univoca de la acción según valores últimos. $\mathrm{O}$, lo que es lo mismo, por la racionalización de la conducta en los términos de una ética de la intención. En palabras de nuestro autor:

«Existen sobre todo dos criterios del grado de racionalización que comporte una religión, que por lo demás están mutuamente enlazados por múltiples relaciones internas. Primero, el grado en que se ha despojado de la magia. Luego, el grado de unidad sistemática que ha conseguido en la relación entre Dios y mundo y, consiguientemente, en la propia relación ética con respecto al mundos ${ }^{34}$.

Pues bien, este doble resultado es el atribuido justamente a la doctina predestinacionista, que en su forma pura es asumida en todas sus consecuencias exclusivamente por el calvinismo, por más que quede perfilada como la solución al problema de la teodicea ofrecida por las religiones teístas de Oriente Próximo y de Occidente.

La elaboración teórica de la predestinación entraña, en efecto, el desencantamiento del mundo en su aspecto teórico, toda vez que la referida imposibilidad de medir los designios divinos con criterios humanos implica, según vemos, una fría y clara renuncia a un sentido del mundo asequible al entendimiento humano, renuncia que pone fin, en suma, a toda problemática de esta especie, dando paso a una concepción del mundo en la que quedan definitivamente escindidas causalidad natural y causalidad ética ${ }^{35}$. El ámbito del dominio intelectual de la naturaleza, y el ámbito de la experiencia religiosa, del deber ser y de la retribución ética, permiten ser vislumbrados, en este

\footnotetext{
${ }^{13}$ Cfr. Einleitung, p. 95; ESR, 1, p. 200.

${ }^{34}$ Resultat, p. $450 ; E S R$, I, p. 419 .

${ }^{35}$ Cfr. «Zwischenbetrachtung: Theorie der Stufen und Richtungen religiöser Weltablehnung», en Gesamtausgabe, o.c, pp. 517 y 521 (citado como Zwischenbetrachtung); ESR, I, pp. 462 y 465.
} 
sentido, como ámbitos diferenciados, con legalidades autónomas y en conflicto virtual ${ }^{36}$. Y es que el proceso de racionalización teórica llevado a cabo por las imágenes religiosas del mundo arroja, según sabemos, el siguiente resultado: cuanto más sistemático se vuclve el pensamiento sobre el «sentido» del mundo, cuanto más consciente se hace de sus contenidos irracionales, más se recluye el problema del sentido y de la salvación en el ámbito no racionalizable. De modo que la racionalización teórica de lo real, del que la misma ética religiosa era resultado, desemboca en un universo de verdades con sus propias leyes, las leyes de lo empíricamente dado, que nada dicen acerca de las originarias pretensiones sobre el «sentido» y la compensación ética ${ }^{37}$. La consecuencia de esta disociación, que posibilita, como vemos, concebir y tratar el ámbito de lo natural bajo el aspecto de lo neutralizado desde una perspectiva ético-religiosa, no puede ser, por una parte, sino la plena intelectualización de lo real: el dominio de todo lo que hay o pueda haber mediante el cálculo y la previsión del funcionamiento de su interna y supuestamente eterna legalidad.

Paralelamente, esa elaboración teórica racionalizada proporciona, por otro lado, un alto grado de unidad sistemática de la relación ética con el mundo. Genera, dice Weber, ciertas estructuras de conciencia práctico-morales que fomentan una postura del sujeto frente al mundo en su conjunto sistematizada en términos de una ética de la intención, en la que quedan también diferenciados lo empíricamente dado de lo normativamente válido ${ }^{38}$. Se trata de un fenómeno de etización religiosa $\rightarrow o$ de subjetivización de lo religioso m del que resulta fundamentada una posición ante el mundo con aspiraciones éticas. El mundo de los fenómenos es ahora tratado bajo el aspecto del deber-ser. Lo que significa que aparece objetivado como escenario de transformación según principios éticos, esto es, como esfera de acreditación ética, como totalidad de situaciones que pueden juzgarse conforme a principios morales últimos y también dominarse a tenor de lo que los juicios morales dicten. A Weber le interesa, en definitiva, resaltar, en este sentído, las conexiones entre la idea de la neutralización ético-religosa del mundo, en cuanto devaluado reino de imperfección, la etización o subjetivización de lo religioso y la idea del reforzamiento moral de ese mundo como ámbito de transformación ético-práctica. Sólo así se entiende el desencantamiento del mundo desde un punto de vista práctico.

Weber considera, en suma, que si la respuesta teórica al problema de la justificación del desajuste entre destino y mérito consiste, con la doctrina de la predestinación, en abismar la distancia entre la legalidad mundana y la divina, la respuesta práctica al mismo consiste en la orientación de la conducta implicada en el mundo según principios morales fijos que ese Dios omnipotente exige. Lo que significa la conquista de una estructura de la personalidad ética

\footnotetext{
${ }^{36}$ Cr. Einleitung, pp. 103-104; ESR, I, p. 206.

${ }^{37}$ Cfr. Zwischenbetrachtung, p. 517; ESR, I, p. 462.

${ }^{2}$ Cfr. Einleitung, p. 117; ESR, I, p. 215.
} 
que sea signo de posesión de la gracia, signo de contacto con lo divino, signo de posesión del sentido definitivamente perdido. $O$ mejor, la racionalización ética del modo de vida: esa «reglamentación sistemática de toda la vida subordinándola al fin religioso ${ }^{39}$. Como vemos, en el caso del protestantismo, que renuncia a medir los designios divinos con criterios humanos, nunca puede el comportamiento ético tener «el sentido de una mejora de las propias probabilidades en este mundo o en el otro, pero sí ese otro sentido que a menudo actúa práctico-psicológicamente con mayor eficacia: el ser síntoma de un estado de gracia merced a un designio divino" ${ }^{40}$. La conquista de una estructura de la personalidad ética a través de la acción se constituye ahora, aunque no en un medio de salvación, sí en ratio cognoscendi del sentido que le ha sido negado a la razón.

Pucs bien, este fenómeno de la racionalización del modo de vida cs circunscrito por Weber a la ética ascética del protestantismo, puesto que sólo ella vincula la acreditación religiosa a una acción ética para la que el mundo devaluado y objetivado ofrece nuevas situaciones y motivos ${ }^{41}$. Explicar de qué manera la ética protestante impulsa esa racionalización ética del modo de vida, exige contar con la «desviación psicológica» de la doctrina de la predestinación. Porque los efectos que las ideas religiosas producen en el terreno de la acción no son para Weber, como apuntamos, directamente deducidos de los contenidos dogmáticos; por el contrario, en ello juegan un papel mediador las implicaciones psicológicas de tales ideas. Weber distingue, en este sentido, entre lo que serían las consecuencias lógicas de la doctrina y las consecuencias de hecho producidas ${ }^{42}$.

La resignación pasiva y fatalista, ya tenida por sabia esperanza o por miedo, o la indiferencia ante el decreto oscuro del destino individual, en cuanto proyecto divino inescrutable y eterno, podrían ser consideradas las consecuencias prácticas lógicamente deducibles de la predestinación ${ }^{43}$. Y, sin embargo, el resultado de hecho es enteramente el opuesto: la orientación metódica de la conducta desde principios ascéticos hacia el dominio práctico-racional del mundo natural y social. «En lugar dc la aparente consecuencia "lógica" del fatalismo, la fe en la predestinación se apropió, en sus más consecuentes adeptos, de los más fuertes motivos imaginables para una acción grata a Dios" ${ }^{44}$. Un tipo de acción que es reconocido como síntoma de la portación del extraordinario carisma

$W G, I I, V, \& 10$, p. $327 ; E S$, p. 427

* $W G, \mathrm{II}, \mathrm{V}, \S 8$, p. $317 ; E S$, p. 415.

* Cfr. Jüngen Habermas, Teoría de la acción comunicativa. Racionalidad de la acción y racionalización social, trad. Manuel Jiménez Redondo, vol. I, Madrid, Taurus, 1987, p. 275 (cit. como TAC).

Cfr. GAR, I, P. 112, n. 4; ESR, I, p. 96, n. 67.

4. Este fatalismo es la consecuencia asumida por el Islam, en el que se afirma el predeterminismo para el destino en este mundo, y no propiamente la predestinación (cfr. GAR, $\mathrm{I}$, p. 101, n. $2 ; E S R, \mathrm{I}$, p. 89, n. 37).

4. $W G, 1 \mathrm{I}, \mathrm{V}, \S 10$, p. 346; $E S, 450$. Cfr. $G A R, \mathrm{I}$, p. 99; ESR, I, p. 86, n. 31. 
de la gracia inmerecida, de la elección, y que se constituye así «en la prueba decisiva (...) de la capacidad de colaborar como instrumento de Dios en su cumplimiento, y de manera continua y metódica, pues la gracia se tiene por siempre o no se tiene» ${ }^{45}$.

Este impeth activista de la doctrina predestinacionista remite, según decimos, a la presencia de un leitmotiv fundamental que emerge allí donde se acoge dicha doctrina en toda su radicalidad y en todas sus consecuencias: la necesidad psicológica de obtener la certeza del estado de elección o reprobación. La incertidumbre absoluta que acompaña a la predestinación se hace psicológicamente insoportable a la larga; parece una necesidad elemental del individuo desembarazarse del tormento de la duda, reclamando la presencia de síntomas que proporcionen certezas fiables de la propia suerte ultraterrena ${ }^{46}$. El interés práctico-religioso tiende, en definitiva, a atisbar la resolución de ese Dios soberano y silente en cada caso particular.

Wcber entiende que el viraje práctico hacia la comprobación de la gracia en las obras se desarrolla paralelamente a la transformación paulatina que experimenta la doctrina de Calvino. La ortodoxia calvinista establece, en efecto, como único criterio de certeza subjetiva cl autotestimonio de la fe permanente, de la fe que persevera finaliter ${ }^{47}$, y rechaza expresamente, por tanto, la existencia de cualquier método que no sea la perdurable confianza que se logra por la verdadera fe. Los elegidos constituyen «la Iglesia invisible de Dios» y no hay ni puede haber atisbos de reconocimiento externo de la elección. La radical devaluación del orden natural cargado de una culpa moral inerradicable, y la idea de trascendencia divina son los fundamentos dogmáticos que permiten desestimar no sólo la vía de acceso externa, institucional, sino también la subjetivo-sentimental como medio de obtener la seguridad de la gracia. Ambas vías incurren, desde esta perspectiva, en idolatría irreverente, viniendo a suavizar el abismo dibujado entre el orden natural y el de los designios divinos. Frente a ello, el individuo es abandonado a sí mismo para recorrer en solitario el camino hacia un destino prescrito desde la eternidad:

«Nadie podía ayudarle; no el predicador, porque sólo el elegido cs capaz de comprender spiritualiter la palabra de Dios; no los sacramentos, porque éstos son, en verdad, medios prescritos por Dios para aumento de su gloria, por lo que han de seguir manteniéndose, pero no son medios para alcanzar la gracia, sino (subjetivamente) simples externa subsidia de la fe. Tampoco la Iglesia, pues aun cuando se afirma el principio extra ecclesiam nulla salus (en el sentido de que quien se aleja de la Iglesia verdadera ya no puede pertenecer al círculo de los elegidos por Dios), a la Iglesia (externa) pertenecen también los excomulgados, quienes deben ser sometidos a su disciplina no para alcanzar de ese modo la eterna felicidad - cosa imposible-, sino porque también ellos deben ser forzados, para gloria de Dios, a observar sus preceptos. Por

t> WG, II, V, $\$ 10$, p. $346 ; E S$, p. 450.

*fr. $W G$, Il, V, \& 8, p. 317; ES, p. 415.

47 Cfr. GAR, I, p. 104, también n. 3; ESR, I, p. 91; cfr. n. 43. 
último, tampoco Dios podía prestar aquella ayuda, pues el mismo Cristo sólo murío por los elegidos, a los que Dios había decidido en la eternidad dedicar el sacrificio de su vida. Este radical abandono (no llevado a sus últimas consecuencias por el luteranismo) de la posibilidad de una salvación eclesiástico-sacramental, era lo decisivo frente al catolicismos 48 .

Son la evolución del calvinismo durante el siglo xvı y la práctica religiosa, la cura de almas, las que van introduciendo ciertas modificaciones en la ortodoxia calvinista, transformando el problema de la constatación subjetiva del estado de gracia en problema cumbre. Entre los epígonos de Calvino y en la religiosidad vivida, más allá de la dogmática establecida, cl problema de la comprobación de la elección va adquiririendo, en efecto, una significación constitutiva. En general, «la cuestión de la certitudo salutis, la cognoscibilidad del estado de gracia, tenía que alcanzar una importancia primordial» ${ }^{49}$ allí donde no se areinterpretó y suavizó la doctrina de la predestinación hasta su virtual abandono» ${ }^{50}$. Allí, pues, aflora la necesidad de comprobación del cstado de salvación, exigiendo indicios, señales que aplaquen la angustia de la duda, y se produce el giro práctico hacia la corroboración de la gracia cn sus efectos, las obras. De este modo, el autotestimonio de la fe perseverante como único criterio de certeza, aunque nunca es abandonado formalmente por la ortodoxia, experimenta un importante giro hacia su comprobación práctica a través de las obras, que serán así no vías de salvación, sino media cognoscendi de una cualidad constante de la personalidad ética, santificada por la gracia. La fe no llega, por tanto, realmente a extirparse, sino que cambia de forma ${ }^{\text {st: }}$ el impulso de la comprobación del estado de salvación exige que la sola fides se convierta en fides efficax. La fe puede comprobarse en sus efectos objetivos y servir de base segura a la certitudo salutis ${ }^{52}$, toda vez que, como reza la ortodoxia reformista, las obras no son sino frutos de la fe actuada por Dios en nosotros. La racionalización ética del modo de vida queda configurada, a esta luz, en sintoma subjetivamente infalible del destino particular, por cualquier otra vía velado. De donde puede concluir Weber que, con todo, «la predestinación otorga al "agraciado" la medida más alta de certeza de salvación, una vez que está seguro de pertenecer a la aristrocacia de los elegidos» ${ }^{53}$. Tarea ésta, no obstante, larga, pues dura toda la vida, y toda la

GAR, I, p. 94; ESR, I, pp. 82-83.

* $G A R, 1$ p. 104; ESR, I, p. 90. Así, aun fuera del pietismo (para el que esta cuestión constituyó una cuestión constitutiva), el problema de la posibilidad de constatar el estado de gracia por el propio individuo ocupó un lugar central a lo largo del xvi1. Prueba de ello es que la Confesión de Westminster admite esta idea de la posibilidad de alcanzar la certitudo salutis a través de la conciencia del cumplimiento del deber. Tarea ésta, la de conseguir la certeza del estado de salvación, que dura toda la vida: «la lucha contra el Maligno dura toda la vida» (West. Conf., XVIII, 3; Apud: GAR, I, p. 104, n. 1; ESR, I, p. 90 n. 41).

GAR, I, p. 105; ESR, I, p. 91.

st Cfr. WG, II, V, $\$ 10$, p. $348 ; E S$, p. 452.

5 Cfr. GAR, I, p. 108; ESR, I, p. 94.

3* $W G, I I, V, \S 10$, p. 346; ES, p. 450 . 
vida y a cada paso en ella el creyente se ejercita en la respuesta a la pregunta que constituye la alternativa: ielegido o condenado?

\section{c) La orientación ascético-racional de la conducta como kratio cognoscendis del estado de salvación}

La necesidad de la «prueba de la fe» en la actividad diaria fue, según acabamos de decir, el impulso positivo hacia la racionalización ética de la conducta: la búsqueda de pruebas de la fe alimentó una disposición racional y un autocontrol metódico de toda la vida en concordancia con el plan divino. Pues bien, ¿qué cualidades de aquellas obras en el mundo atestiguan la rectitud de la fe hasta convertirse en infalible síntoma del «destino» individual? La respuesta es tan ajustada a la visión teocéntrica del mundo como ésta: el elegido se reconoce en aquel «estilo de vida» que tiende a conformar la actividad en este mundo según la voluntad de la divinidad ${ }^{54}$ y sirve así al aumento de su gloria, fin último de la creación y del hombre mismo, en cuanto parte suya. $O$ de otro modo: en aquel modo de vida que de forma metódica y constante continúa el plan divino en el mundo.

Esta vía de salvación, solución práctica que pretende estrechar el abismo teóricamente establecido entre una cultura culpada y su creador, se deduce directamente de la revelación bíblica, de la concepción de un Dios creador y ordenador del mundo y del hombre como instrumento suyo, e indirectamente, del orden finalista de la naturaleza ${ }^{55}$. Toda actividad humana dirigida a ese fin objetivo e impersonal: a promover la teleologia impuesta, entendida como servicio in maiorem Dei gloriam, será, en este sentido, no sólo querida por Dios, sino actuada por él ${ }^{55}$. Pues bien, sólo cuando el individuo que actúa toma conciencia de que el modo sistemático y unitario de conducirse en la vida resulta ser expresión de algún «impulso» o principio que vive en él, que permanece en él como síntoma de una personalidad moral unificada en torno a ese valor-fin supremo religioso, sólo entonces alcanza el sumo bien al que aspira: la certidumbre de la gracia. La conciencia, entonces, de que la actuación es síntoma de una personalidad moral otorga la seguridad de ser instrumentos de la divinidad y de pertenecer al grupo de los elegidos. Porque «sólo el elegido tiene propiamente fides efficax, sólo él es capaz - gracias a la regeneratio y la consiguiente santificatio de su vida entera- de aumentar la gloria de Dios mediante obras realmente, no sólo aparentemente, buenas ${ }^{57}$.

Weber subraya, según esto, que los frutos de la fe han de constituir un «estilo de vida», entendiendo por tal no un mero acopio de acciones aisladas

\footnotetext{
${ }^{44}$ Cfr. Zwischenbetrachtung, p. 113;ESR, I, p. 212.

${ }^{5 s}$ Cfr. $G A R$, I, p. 109; ESR, I, p. 95.

${ }^{56}$ Cfr. $G A R, 1$, p. 101; ESR, 1, p. 88.

"GAR, I, p. 110; ESR, I, p. 95.
} 
éticamente valiosas, sino un obrar sistemático, un sistema unitario de vída en el que las acciones éticas particulares quedan integradas como «síntomas o expresión de una personalidad morals ${ }^{58}$ santificada. Las obras meritorias aisladas entran meramente en consideración en su calidad de síntoma y expresión de un habitus religioso, una total estructura de la personalidad ética, consecuencia de la intervención sobrenatural de la gracia divina. Pues «el Dios calvinista no exigia de sus fieles la realización de tales o cuales "buenas obras", sino una santidad en el obrar elevada a sistemas ${ }^{59}$. La conducta moral que pueda confirmar la certeza de salvación tendrá que configurarse, en suma, en un modo de vida metódico, planificado y racionalmente guiado por un incondicionado valor/fin religioso. Este estilo de vida, que representa la ascensión del hombre del estado de naturaleza al estado de gracia, sólo puede significar, sin duda, «la transformación fundamental del sentido de la vida entera en cada hora y en cada acción» ${ }^{60}$.

La metódica conducción de la vida hacia el bien religioso, el obrar moral elevado a sistema es, por tanto, un medio de autoconocimiento del estado de salvación. A través del permanente autoexamen de la cualidad moral de su actuación cotidiana, de su sujeción a la ley impresa en toda la naturaleza, el sujeto puede autorreconocerse portador de la gracia y superador del status naturae La acción, o mejor, el obrar cotidiano metódicamente racionalizado como «vocación», permite descubrir así lo que el hombre invariablemente «es» por lo que hace ${ }^{61}$. Weber encuadra en esta tradición cristiana de pensamiento la sentencia goethiana que hace del obrar moral el único medio de autoconocimiento, y de la acción, en suma, frente a la contemplación, el camino de salvación. Tradición de pensamiento por la que el principio délfico del «conócete a tí mismo» transforma su originario significado y queda puesto al servicio de la moralidad cristiana ${ }^{62}$. Acción por deber y autoconocimiento salvífico permanecen, en definitiva, ya inseparablemente ligados: « ¿Cómo puede uno conocerse a sí mismo? Nunca mediante la introspección, sino más bien

$W G, 11, V, \S 10, p, 324 ; E S, p .423$.

SAR, 1, p. 114; ESR, I, p. 98.

GAR, I, p. 115; ESR, I, p. 99.

b1 Cfr. $W G, \mathrm{II}, \mathrm{V}, \S 10, \mathrm{p}, 348 ; E S$, p. 452 . El fuerte influjo del protestantismo en la filosofía norteamericana se hace patente en esta idea calvinista que viene a discriminar las acciones con significado ético-religioso por sus efectos. Sería, cn este sentido, un criterio pragmático el que permite el autoconocimiento del estado de salvación. En clave filosófica identifica Peírce la esencia de una cosa con su comportamiento. Y en Cómo esclarecer nuestras ideas trata de mostrar que, lejos de ser la máxima pragmática un principio escéptico y materialista, es meramente auna aplicación del único principio de lógica recomendado por Jesús: "por sus frutos los conoceréis", y está íntimamente vinculado a las ideas del evangelion (art. cit. en El hombre, un signo, Barcelona, Crítica, 1988, p. 210, n. 6). Parece evidente: más que un influjo es una traslación de ideas desde el contcxto religioso al filosófico.

"2 Siguiendo a Foucault, el principio délfico gnothi seauton era una regla práctica observable antes de consultar el oráculo relacionada con el "cuidado de sí» (epimelesthai seautou), que la tradición cristiana acaba soslayando al hacer formar parte del "conocimiento de sì la "renuncia de sím (cfr. Michel Foucault, «Tecnologías del yo», en Tecnologías del Yo y otros textos afines, 
a través de la acción. Trata de cumplir con tu deber e inmediatamente sabrás lo que hay en ti» ${ }^{63}$. Es más: el parentesco entre Goethe, Weber y la tradición protestante descrita se estrecha al cifrar como contenido de ese deber las «exigencias de cada día» (die Forderung des Tages). «Sólo por una incesante actividad es como se manifiesta el hombre», indicaba Fausto convencido tras sellar su pacto con Mefistófeles ${ }^{64}$. Acción como medio de conocimiento y técnica de salvación y de «tecnología» del Yo, como precisa Foucault. Un tipo de acción unitariamente guiada por valores e implicada en las exigencias puntuales de los diversos órdenes vitales, los cuales vienen a representar, desde esta perspectiva, la ocasión y el estímulo para que el sujeto compruebe su destino individual: «material para conformar éticamente según principios ascético-racionales» ${ }^{65}$.

Pues bien, la repercusión en el terreno de la acción de la doctrina de la predestinación y de la necesidad de certeza de salvación, vinculada a ella, no puede ser, por tanto, sino el réforzamiento de la racionalización práctica. El determinismo de la predestinación se constituye, en este sentido, en el medio de centralización más intensamente sistemático imaginable de la ética de convicción ${ }^{66}$, de una ética absoluta que al tomar como criterio de valor la intención misma de la acción se desarrolla con independencia de las consecuencias, esto es, de espaldas a la habitual lógica paradójica que atraviesa la actuación en los distintos órdenes vitales. De manera que si klas consecuencias de una acción realizada conforme a una ética de la convicción son malas, quien la ejecutó no se siente responsable de ellas, sino que responsabiliza al mundo, a la estupidez de los hombres o a la voluntad de Dios que los hizo así (...) El cristiano obra bien y deja el resultado en manos de Dios» ${ }^{67}$.

Parece obvio que la vida del «santo» descrita en estos términos se encaminaba únicamente hacia una finalidad trascendente, la bienaventuranza; pero, ujustamente por eso, el decurso de csa vida fue absolutamente racionalizado y dominado por la idea exclusiva de aumentar la gloria de Dios en la tierra;

Paidós lbérica, Barcelona/Buenos Aires'México, ICE de la Universidad Autónoma de Barcelona, 1990, pp. 45-94).

${ }^{6}$ Apud: GAR, I, p. 111, n. 2; ESR, I, p. 95, 11. 65. Esta sentencia citada por Weber en La ética protestante... y parafraseada también al final de la Ciencia como vocación, corresponde, como señala J. María González en «La herencia de Kant en el pensamiento de Max Weberm, en J. Muguerza y R. Rodtíguez Aramayo (eds.), Kant, despues de Kant, Madrid, Tecnos, 1989, p. 500, a los aforismos 2 y 3 de «Betrachtungen im Sinne der Wanderer», en Spriche, vol. 6, Insel Verlag, p. 451. La relevancia de la acción cn el pensamiento de Goethe permite establecer ел este punto un paralelismo con el de Weber y la tradición protestante que describe.

${ }^{64}$ J. W. Goethe, Fausto, I, Madrid, Cátedra, 1987, p. 153.

is Resultat, p. 460; ESR, I, p. 425.

Cfr. $W G, I I, V, \$ 10$, p. $452 ; E S$, p. 452 . "Nunca se ha dado una tan elevada estimación de la conducta moral como la que el calvinista inculca en sus adeptos) (GAR, I, pp. 112-113; ESR, I, p, 97),

${ }^{67}$ Max Weber, "La política como vocación», en El politico y el cientiffico, Madrid, Alianza, 1986, p. 164. 
jamás se ha tomado más en serio este principio de omnia in maiorem Dei gloriam» ${ }^{68}$. En este punto, Weber subraya el modo como el protestantismo ascético ha sabido extraer a partir de la negación radical del mundo los fundamentos para una actitud racional-dominadora ante el mismo. No la huida contemplativa, ni la espera pasiva en la fe, sino la transformación metódica del orden cotidiano según ideales ascéticos; tal es el tipo de conducta que impulsa el ethos del protestantismo ascético. Así resulta que «cuando el virtuoso de la religión se encuentra en el mundo como "instrumento" de un Dios, separado de todos los medios mágicos de salvación, con la exigencia de "probarse" como llamado a la salvación ante Dios, y, lo que en realidad es equivalente, ante sí mismo, por la moralidad de sus acciones en el orden del mundo y sólo por ellas, cuanto más se desprecie y se rechace religiosamente el "mundo" en cuanto tal por su carácter no espiritual y por ser sede del pecado, más se afirma psicológicamente, como escenario de la actividad querida por Dios, en la "profesión" mundanas" 69 .

Esta centralización de la acción cotidiana en una ética de convicción viene a perfilar el ideal de personalidad que Occidente consolida, ideal que -como señala Foucault- ha ido elaborándose sacrificando el significado originario del precepto griego del «cuidado de uno mismo», por virtud de la subordinación de este precepto al principio délfico "conócete a ti mismo» transformado por esta tradición propiamente en «renuncia de uno mismo», del yo propio para constituir un nuevo yo ${ }^{70}$. El ascetismo puritano se afanaba, en efecto, en capacitar a los hombres en la afirmación de sus «motivos constantes» frente a los «afectos»; aspiraba, por tanto, a educarlos como "personalidades» ${ }^{71}$. Por personalidad se entiende, según esto, el resultado de la autoapropiación y seguimiento incondicionado de valores últimos, por encima de sentimientos y deseos. En esencia consiste en la permanente sumisión reflexiva y, por ello mismo, libre hacia algo supraindividual, a valores que se constituyen en fines áltimos de un tipo de acción que será así acción teleológica racional. La personalidad, en palabras de Weber, sencuentra su "esencia" en la invariabilidad de sus relaciones interiores con los "valores" y "significados" últimos de la acción convirtiéndola en una acción teleológica racional» ${ }^{72}$. Esta personalidad

GAR, I, p. 115;ESR, I, p. 99.

${ }^{69}$ Einleitung, p. 114; ESR, I, p. 213.

" Cr. M. Foucault, o.c. En la línea de interpretación del ideal de sujeto esbozado por Occidente, en el que tanto papel juega, scgún vcmos, esa expresión racionalizada del cristianismo que para Weber es el protestantismo, resulta asimismo muy interesante mostrar la conexión de sentido existente entre la valoración ético-religiosa de la subjetividad como espacio exclusivo de contacto con lo divino llevada a cabo por la tradición reformada, y la conformación de un nuevo ideal de las relaciones entre los géneros. Cfr. a este respecto el sugerente análisis de Célia Amoros, Tiempo de feminismo. Sobre feminismo, proyecto ilustrado y posmodernidad, Cátedra, 1977, pp. 85-107.

${ }_{71}$ Cfr. GAR, I, p. 117; ESR, I, pp. 100-101.

"Max Weber, Gesammelte Aufsätse zur Wissenschafislehre. Zweite durchgeschene und crgänzte Auflage, besorgt von Johannes Winckelmann, J. C. B. Mohr (Paul Siebeck), Tübingen, 1951, p. 132 (citado como $W L$ ); trad. cast. de J. M., García Blanco, «El doble aspecto de lá categoría 
ética se traduce, por tanto, en una forma de vida ascética ordenada sistemáticamente conforme a motivos constantes, en la que afectos y pasiones quedan sometidos a control racional. Racionalización de la conducta según valores, desde una voluntad firme internamente relacionada con ellos, es la característica que distingue la personalidad ética. Tiene como único fin supremo superar el estado de la espontaneidad natural: «la mera virtud "natural" dentro del mundo no sólo no garantiza la salvación, sino que la pone en peligro, porque distrae de 10 único que es necesario» ${ }^{73}$.

El carácter ascético-racional del estilo de vida que la ética protestante impulsa y de la estructura de la personalidad ética que le subyace se deja sentir con evidencia en un doble sentido: en cuanto consiste en una sistematización racional de la conducta en su totalidad, y en la medida en que rehúsa a todo lo éticamente irracional dentro del mundo y de su orden ${ }^{74}$. Desde la perspectiva devaluadora de lo creado en cuanto naturaleza caída, lo éticamente irracional ticne que identificarse en esta tradición con el ámbito estrictamente natural y con la cultura material. Así pues, el autodominio de la naturaleza interna y el dominio de la naturaleza extcrna resultan, obviamente, los rasgos primarios de esa dura racionalidad del ethos ascético protestante que mueve al devoto a disciplinar su conducta en la vida al servicio de un fin más alto.

La concepción ética del propio Weber sucumbe a los ideales de la tradición analizada. La relación interna de la acción con valores es también el fundamento, a la vez que el síntoma, de la personalidad y de la dignidad humanas, por cuanto permite al individuo emanciparse del curso de la naturaleza y ser creador responsable de su propio destino. Pero, como cabe suponer, en el caso de Weber los valores que dirigen la conducta, $y$ el sentido que ella adquiere por la orientación valorativa, se encuentran plenamente secularizados. Para el calvinismo, es la revelación, en definitiva, la que proporciona el ideal último de actuación, mientras que para él no puede ser sino una racionalidad subjetiva la que elije, entre todos los valores que «a la carta» le ofrece una cultura desdivinizada, aquellos cuyo seguimiento otorgará un sentido unitario a la vida de quien actúa conforme a la elección realizada. Pero además estos fines últimos, motivos constantes de actuación, en función de los cuales el sujeto adquiere su dignidad como «personalidad» ética, son los fines que la tarea profesional-vocacional impone en cada caso. De manera que el ideal de personalidad moral que Weber tiene en mente queda lejos de identificarse con el que la Bildung dibujaba desde Humboldt, haciéndose eco de la tradición ilustrada ${ }^{75}$.

de la causalidad y la relación entre racionalidad e indeterminismos, en El problema de la irracionalidad en las ciencias sociales, Madrid, Tecnos, 1985, p. 158.

${ }^{73} W G, \mathrm{II}, \mathrm{V}, \S 10, \mathrm{p}, 329 ; E S, \mathrm{p} .428$.

${ }^{74}$ Cfr. L.C., p. $330 ;$ L.C., p. 430.

"Sobre esto, cfr. H. Goldman, Politics, Death and the Devil, Self and Power in Mox Weber and Thomas Mann, University of California Press, Berkeley, Los Angeles, Oxford, 1992, cap. 2 
Me refiero al ideal aristocrático de «formación» de sujetos que se desarrollan armónicamente desde sí mismos, autodesplegando la totalidad de sus potencialidades teóricas, estéticas, eróticas, éticas... La elevación espiritual, el refinamiento afectivo-estético y el perfeccionamiento moral permanecen, desde este ideal educativo, armónicamente integrados en el desarrollo del sujeto y de la humanidad. Weber reconoce que en la Modernidad el sujeto aparece ya profundamente dividido en múltiples formas de ser que descomponen su supuesta identidad, y que sólo puede lograr su dignidad en la elección y la renuncia, en la entrega apasionada a una vocación y en la sujeción a los imperativos que el desarrollo cotidiano de esa vocación elegida le impone.

A estas alturas de exposición resulta ya obvia la continuidad de «sentido» entre el ascetismo monacal cristiano (ascetismo extramundano) y este tipo de ascetismo «vuelto al mundo» (intramundano). En sentido religioso, la noción de "ascetismo" se aplica a la ejercitación en el cumplimiento de un designio divino de carácter ético. Ambas formas de vida ascéticas representan, sin duda, el esfuerzo por superar cl estado de naturaleza mediante la centralización de la existencia en una ética según principios. Pero el ascetismo protestante se caracteriza y distingue del ascetismo extramundano de las órdenes monacales por su interesada implicación en la transformación técnico-pragmática del mundo, pues sólo esta transformación permite al piadoso autorreconocerse como verdadero instrumento divino ${ }^{76}$. Frente a la «huida ascética del mundo» como medio de salvación propia del ascetismo monacal, el dominio racional de todos los órdenes de realidad es lo propio del ascetismo «vuelto al mundo» del protestantismo. Asi:

«No castidad, como en el monje, sino apartamiento de todo "placer" erótico; no miseria, sino eliminación de todo goce rentístico y de toda ostentación alegre feudal de las riquezas; no mortificación ascética en el convento, sino un estilo de vida alerta, estrictamente racional, cvitando toda entrega a las bellezas del mundo o del arte, $o$ a los propios sentimientos y estados de ánimo. Éstas son las exigencias, y la disciplina y método en la conducta de la vida el único fin» ${ }^{n}$.

Lo novedoso de esta ética reformada consiste, en suma, en haber ampliado el imperativo ascético a todos los creyentes y en haberlo vinculado a toda práctica vital, produciendo así «una penetrante cristianización (Christianisierung) de toda la existencias ${ }^{78}$. Se abrieron los claustros y, con ello, se pusieron barreras a toda práctica ascética de espaldas al mundo. El resultado no pudo scr otro que «la fundamentación de la ética profesional», que hizo surgir en lugar de la aristocracia eclesiástica de los monjes, situados fuera y por encima

sobre todo. Asimismo, J. M." González Garcia, Las huellas de Fausto. La herencia de Goethe en la Sociologia de Max Weber, Madrid, Tecnos, 1992, pp. 122-142.

${ }^{76}$ Cfr. L.C., p. $329 ;$ L.c., p. 429.

"L.c., p. 337; ES, p. 439.

${ }^{7} G A R$, I, p. 124; ESR, I, p. 105. 
del mundo, «la de los "santos" en el mundo; predestinados por Dios desde la eternidad, una aristocracia que con su character indelebilis estaba separada del resto de los hombres, condenados también desde la eternidad, por un abismo mucho más insalvable y terrible en su invisibilidad que el que separa exteriormente del mundo al monje medieval» ${ }^{79}$.

$\mathrm{Y}$ es que esta forma de protestantismo, al vincular la ética ascética con la idea de la comprobación de la fe, consiguc aplicar las estructuras de conciencia práctico-morales que resultan de la racionalización ético-religiosa a todos los ámbitos extrarreligiosos. Filtra, pues, en el ámbito de la práctica profesional la estructura de pensamiento que ya existía - aunque «enclaustrada»- en el plano cultural -en la ascesis religiosa del medievo- ${ }^{80}$. $O$, dicho de otro modo: el ethos del protestantismo ascético logra que la acción racional conforme a valores se eleve a principio rector de la actividad racional conforme a fines: que toda actividad según fines adquiera un carácter de práctica «vocacional».

\section{d) Resultado: Un sujeto objetivador del mundo como ámbito de dominación racional teleológica}

La metódica conducción de la acción hacia el dominio ascético-racional de la naturaleza externa e interna queda constituida, en definitiva, en una tarea-misión cargada de valor religioso, a través de la que el piadoso puede atisbar su destino. Los procesos naturales, sociales y subjetivos, objetivados de este modo como ámbito de completo dominio racional-telcológico son el escenario legítimo en el que acontece el conocimiento de un si mismo unitario (personalidad), único medio de conseguir la certeza de salvación buscada. Puesto que Dios es plena racionalidad dominadora del mundo, el llamado eficazmente a la salvación se reconocerá como tal, esto es, como instrumento de la divinidad, si los efectos de su fe reflejan un ejercicio sistemático hacia el dominio de su porción de mundo según principios ascéticos. Más aún: se interpretan «las exigencias de Dios a las criaturas en el sentido de un incondicional señorío del mundo por la norma de la virtud religiosa y hasta su transformación revolucionaria para conseguir este fin ${ }^{81}$. Pues bien, ese fin-valor debe cumplirse en el tiempo que dura la vida completa del sujeto. Y la porción de mundo, espacio en el que ha de actuar por deber, coincide con el marcado por la actividad diaria ${ }^{82}$. Como sabemos, una forma tal de orientación ascética ejercida en una profesión, además de ser el medio de conocimiento del estado de salvación, cumple paralelamente la función higiénico-psicológica de liberar al sujeto de la angustia de la duda que el decreto de la predestinación provoca,

L.c, p. 119; L.c., pp. 102-103.

\$o J. Habermas, TAC, I, p. 284.

81 $W G$, II, V, \& 10, p. 333; ES, p. 434.

${ }^{82}$ "El hacer las obras del que me envió mientras "dure el día" se convirtió on un deber, y estas obras no eran de carácter ritual, sino ético-racional», Resultat, p. 467 ; ESR, I, p. 429. 
y que paraliza la acción, tanto más cuanto que la duda por sí misma es interpretada desde la ortodoxia calvinista como consecuencia de una fe insuficiente $y$, por tanto, como síntoma de la carencia de la gracia ${ }^{83}$.

La cntrega metódica y disciplinada al trabajo abnegado en una profesión adquicre así un nuevo sentido frente al luteranismo: ya no consiste en el lugar en el que la divinidad ha colocado a cada cual y a cuya lógica hay que conformarse pasivamente, sino que representa propiamente la tarea de sujeción legisladora de lo dado en su conjunto. Sujeción por obra de una subjetividad que impone una lógica instrumental dominadora hacia los procesos mundanos, externos e internos, como el medio legítimo de acercamiento cognitivo y práctico a ellos. Ya no se sirve entonces a Dios in vocatione, sino per vocationem. Como tampoco se valorará obviamente por igual cualquier tipo de actividad: ahora adquiere exclusivamente valor religioso aquella que sea expresión esencial de un metódico estilo de vida ascético-racional (methodisch-rationale Lebensfiihnung) orientado a la configuración y control racional-teleológico de toda la realidad. A la implantación del reino de Dios en la ticrra mediante la «restauración» del poder adánico perdido sobre ella, como señalara Bacon. La santificación, por un lado, de todo producto, consecuencia derivable necesariamente de ese estilo de vida máximamente racional, queda asegurada. Pues aunque el obrar por convicción desatienda, como no puede ser de otra mancra, los resultados del obrar, el éxito que se allega a él puede considerarse, sin embargo, indirectamente señal de la gracia: «Cuando el asceta obra en unidad consigo mismo está seguro de ser un instrumento de Dios» (...). Pero «el éxito de su acción es ya un éxito del mismo Dios, al que ha colaborado, o por lo menos una señal de su bendición» ${ }^{84}$. De otro lado, queda además reforzado - desde esta concepción del sujeto como instrumento- el carácter ascético de las relaciones que ha de mantener ese sujeto con los resultados de su obrar. El hombre debe servir, en efecto, de mero «administrador» de los resultados del ejercicio ascético profesional; por lo que tal práctica se desarrollará en permanente oposición al hedonismo que más tarde reclamará para sí el capitalismo desarrollado. Ni que decir tiene que un tipo de hombre como el que va siendo perfilado aquí es, en definitiva, el ideal de sujeto adecuado al desarrollo del capitalismo industrial: el que sustituye el lujo por la aspiración a la obtención de beneficios mediante la organización racional del trabajo, animado permanentemente por acrecentar la productividad mediante la conversión de la ciencia en esencial fuerza productiva. Pero también se atisba el rostro del individuo sometido a los imperativos, fines, que el cargo/profesión impone: el del trabajador sobrio y concienzudo disponible para la explatación de su buena voluntad ${ }^{85}$.

${ }^{13}$ GAR, I, p. 104; ESR, I, p. 91.

" $W G, I I, V, \$ 10$, p. $332 ; E S$, p. 433.

* Cfr. Marianne Weber, Max Weber. Una biografia, Generalitat Valenciana, Edicions Alfons El Magnànim, 1995, p. 514. 
La vinculación de la acreditación religiosa a la racionalización ascética de la vida profesional permite, como decimos, la plena objetivación del mundo como oportunidad de cualificación ética mediante su completo dominio racional-tclcológico. Una subjetividad que busca la certeza de salvación en sí misma y desde sí misma, desde la autoconciencia de ser un instrumento eficaz de la divinidad orientado a continuar su obra creadora, a acrecentarla, organizarla y administrarla para gloria de su creador, consolida así una imagen del mundo como cl escenario de su absoluto dominio práctico-instrumental. Esta imagen sólo resulta posible, como hemos visto, sobre una concepción dualista del mundo (que pone su fundamento allende el mundo) y devaluada del mismo (en cuanto sede de culpa permanente) en sentido ético-religioso. Sin duda. Pero la peculiaridad de la vía protestante de salvación consiste en haber extraído de la negación judeocristiana del mundo el impulso para su completo dominio ascético-racional. En haber favorecido el ideal de sujeto moderno constituido desde el entrecruzamiento de la racionalidad conforme a valores y conforme a fines. $O$, de otro mundo, un sujeto cuya acción orientada a fines (dominio teleológico) permanece fundamentada conforme a valores (salvación personal).

El avance del proceso de modernización se encargará de desechar, sin embargo, el originario fundamento religioso de la racionalización de la conducta conforme a fines. La racionalidad práctico-moral de la ética ascética parece no poder institucionalizarse en la sociedad cuyo inicio ella hace posible, $Y$ así, mientras que el asceta cifró en «la acción racional, unívoca, según sentido, medios y fines, según principios y reglas ${ }^{86}$ el camino de su propia salvación personal, para su heredero, el hombre profesional moderno, tal tipo de conducta representa un impcrativo pragmático cuyo sentido se mide por el resultado: la adaptación con éxito a los procesos económicos ${ }^{87}$. Sólo cuando ello ocurrre, cuando se secan definitivamente las raíces religiosas originarias, se vuelve plenamente eficaz la idea del deber profesional. Que esto suceda supone, de un lado, que el proceso de modernización se manifiesta necesariamente como un proceso portador de un mecanismo autodestructor de la racionalidad valorativa. Pero además viene a señalar la presencia del ethos y de la cultura profesional como destino de la modernidad.

La paradoja hace acto de presencia en esta relación de parentesco mostrada hasta aquí entre ciertas ideas religiosas negadoras del mundo y el desarrollo de una racionalidad dominadora del mundo, no sólo necesariamente de espaldas

${ }^{8} W G, I I, V, \S 10$, p. $333 ; E S$, p. 433

67. En su fase ayanzada el capitalismo no necesita de un fundamento práctico-moral de la racionalización de la conducta en tomo al ejercicio profesional; el «sistema» económico funciona perfectamente desde fundamentos mecánicos. $Y$ ese tipo de conducta, que es funcional a su perpetuación, resulta ser simplemente la respuesta adaptativa que «el látigo del hambres impone. El puritano quiso ser un hombre profesional por convicción, nosotros estamos obligados a serlo como resultado de la simple coacción económica (cfr. GAR, 1, p. 165.) Sobre esto ver el cap. 3, especialmente pp. 186-210, de mi trabajo Racionalidad y conciencia trágica. La Modernidad según Max Weber, Madrid, Trotta, 1996. 
ya a todo sentido religioso, sino, lo que es más importante, incapaz ella misma de otorgar un sentido a la acción más allá del puramente técnico-adaptativo. La pérdida de sentido es, en efccto, el balance general arrojado por este proceso de constitución de la modernidad; pérdida representada en ese reemplazamiento de la racionalidad valorativa por la racionalidad de medios y fines. En malos resultados parecen, pues, transformarse las buenas intenciones, por virtud de una cierta lógica formalizante y reificante que parece funcionar en la historia del desarrollo de la razón occidental.

Weber entiende, en efecto, que el ascetismo protestante ha estado transido de una cierta lógica paradójica, azarosa y hasta fatal que ha hecho de ćl, como destino, «la fuerza que siempre quiere el bien y siempre crea el mal» ${ }^{88}$ : que ha hecho que la originaria orientación moral-escatológica favorezca a la larga, y a su pesar, una orientación pragmática al dominio del mundo. El puritano buscaba la salvación personal a través de la entrega al ejercicio profesional. El capitalista moderno racionaliza la conducta conforme a la maximización de beneficios por imperativos puramente pragmáticos y funcionales. El mundo, por su parte, negado en aras de su transformación racional según ideales últimos, se afirma ahora tal cual es como el eterno Paraíso. El hombre, mero instrumento de la divinidad, deviene ahora un Dios sin dioses. $\mathrm{E}$ lascetismo protestante aparece, en suma, a esta luz, como matriz generadora de frutos no queridos: de un tipo de conducta teleológica motivada por fines pragmáticos (intereses, no valores), y, en general, de una cultura racionalizada como es la capitalista, orientada csencialmente a la inmanencia ${ }^{89}$, absolutamente secularizada y hedonista. Nada más alejado de las pretensiones originarias de toda religión de salvación racionalizada que estas consecuencias.

Finalizamos con un texto de Marianne Weber que parafrasea otro texto de sobra conocido de su marido, en el que se abunda en la retirada del fundamento práctico moral de la racionalización de la conducta conforme a fines: en la clevación de ésta a valor en sí mismo, dando cuenta del' hecho general de la presencia de una lógica perversa interna al desarrollo de toda idea, lógica que arruina, por tanto, su sentido originario. $O$, dicho a lo Simmel, dando cuenta de cómo el espíritu objetivado se desarrolla conforme a una lógica independiente y opuesta al sentido de su ser ${ }^{90}$ :

"Die Kraft, die stets das Gute will und stets das Böse schaft», GAR, I, p. 191; ESR, I, p. 165. Aquí Weber invierte la definición que Mefistófeles hace de sí mismo ante Fausto como auna parte de aquel poder que siempre quiere el mal y siempre obra el bien* (J.W. Goethe, Fausto, cd. cit., p. 144). Con esta inversión, Weber niega toda teleología positiva oculta en la Historia, todo sentido predeterminado de la misma, oponiéndose, por tanto, a una amplia tradición moderna e ilustrada defcnsora de la idea de progreso. Véase sobre esto el artículo de J. M. ${ }^{2}$ González, "Las herencias de Kant y Goethe en el pensamiento de Max Weber», REIS, núm. 43, 1988 , pp. $23-42$.

Cfr. GAR, I, p. 82; ESR, I, p. 73 .

* Para Simmel la tragedia de la cultura se asicnta precisamente en el hecho de que la lógica intema del desarrollo de los objetos culturales se independice del sentido del ser de esos objetos. 
«La preocupación por los bienes terrenales deberia pesar en los hombros de sus santos sólo como un temue abrigo que se podrían quitar en todo momento. Pero la fatalidad hizo del abrigo un caparazón duro como el acero. Hoy ha desaparecido del caparazón el espíritu religioso. ¿Definitivamente? ¿Quién lo sabc? Al final, Weber extiende la mano por un momento hacia el velo que cubre el futuro de este inmenso desarrollo, pero no se atreve a levantarlos ${ }^{\prime 1}$.

Cfr. «El concepto y la tragedia de la cultura», en G. Simmel, Sobre la aventura. Ensayos filosóficos, Península, pp. 204-231.

"L.c., p. 514 . 